\title{
COMMUNITY DEVELOPMENT WORKERS: FOUR LESSONS FROM INTERNATIONAL EXPERIENCE OF COMMUNITY-BASED WORKERS
}

\section{D van Rooyen}

\section{INTRODUCTION}

Although the Department of Health has been using community health workers since 1994 (Friedman, 2002), it was not until 2003 that the South African government introduced the Community Development Workers Initiative (Department of Provincial and Local Government [DPLG], 2005). The primary aim of Community Development Workers is to maintain direct contact with people where they live and to assist in developing a community/people-centred drive (DPLG, 2005:13). The introduction of community development workers is an initiative stemming from the Office of the President. The main vision for the community development workers is captured in President Thabo Mbeki's State of the Nation Address in February 2003, when he stated that "government will create a public service echelon of multi-skilled Community Development Workers who will maintain direct contact with the people where these masses live. We are determined to ensure that government goes to the people so that we sharply improve the quality of the outcomes of public expenditures intended to raise the standards of living of our people" (Baaitjies \& Hinstra, 2005:10; DPLG, 2004). The initiative is viewed as contributing to a removal of the "development deadlock", strengthening the "democratic social contract", advocating for an organised voice for the poor, improving the government-community network and contributing to "joined up" government. According to this initiative, most electoral wards should have a community development worker. Although the current documentation provides a fairly good overview of what is expected of these community development workers, the question is what one can learn from international experience in this regard. Interestingly, South African academic literature has been over-supplied with contributions focusing on the international experience in respect of community developmental policies during apartheid and the early 1990s (Cruse, 1997; Finger, 1999; Friedman, 2002; Frontiers, 2002; Holloway, Lee \& McConkey, 1999; Makan, 1997). However, lately there has been a decrease in papers focusing on this debate. Also, none of the above-mentioned papers has focused on international experience in respect of community-based workers. Considering the government of South Africa's introduction of community development workers and initiatives such as those involving community-based workers, the question is: what can we learn from international experience that we can apply in South Africa? These lessons from best practices across the world will surely be able to inform implementation, policy and legislation in developing the community development worker approach in South Africa.

\section{Aim and methodology}

It is important to note that both internationally and nationally there is not an abundance of literature available on community-based workers. This may be due to an emphasis within development literature on impact and outcomes-based analyses, rather than on the nuts and bolts of how interventions happen, and who and what, at the micro level, are involved in implementation. There are suggestions of best practice (how organisations have made use of the community-based worker) (Steinitz, n.d.; Jones, 1999; Rozemeijer \& Van der Jagt, 2000; Sivaram \& Celentano, 2003; Riviere-Cinnamond \& Eregae, 2003; Morgan, 2000; Morreira, 1999; Leksmono \& Young, 2002), but to date documentation is limited to the human resource issues of sustainability, developmental impact, motivation, retention and the training of community-based workers. This article thus aims to highlight important lessons from the international community 
on community-based workers and vital issues that should be taken note of when conceptualising the implementation of a community-based worker programme.

A comprehensive search (African and international) was undertaken on the internet by using search engines (GOOGLE \& AARDVARK) for any/all possible documentation available on community-based workers (CBWs), community development workers (CDWs), communitybased health workers (CBHWs), community-based distribution (CBD), community-based animal health workers (CAHWs), community-based care and support (CBC\&S), community-based coastal resource management (CBCRM), community-based natural resource management (CBNRM), community-based rehabilitation (CBR), and community-based monitoring and evaluation (CBMES). The websites of different organisations involved in community-based work were also accessed. For further documentation, the information officer at the Sasol Library of the University of the Free State performed a thorough search on different databases available to the university. These included Kovsiedex, EBSCO Host, SA Publications and Swetswise Online. Academic journals and government documentation were also accessed. Case studies were selected from information accessed through the searches. In addition, a number of possible contacts generated through the searches were followed-up by email.

Against the above background the paper gives an overview of the relevant policy development and provides background to the community development worker system in South Africa. In respect of the operationalisation of community-based workers in South Africa, the article then highlights four essential lessons to be learnt from international experiences on how to improve community-based worker programmes and then applies these to community development worker practice in South Africa.

\section{WHAT ARE COMMUNITY-BASED WORKERS?}

There is no common terminology to describe community-based workers or the functions they perform; the terminology depends on the specific context in which they operate (e.g. community health workers (CHWs), community animal health workers (CAHWs), community home-based carers (CHBC), community forestry advisors, community development workers (CDW), etc). Typically, job descriptions (and therefore also definitions) may vary from the community homebased carers (CHBC) providing care to people in their own homes, to community-based health workers acting as agents for health promotion, care and health development. They also provide local outreach for health services which were otherwise unavailable (Friedman, 2002:161). Furthermore, a community-based rehabilitation worker (CBRW) promotes the rehabilitation, equalisation of opportunities and social integration of all people with disabilities (WHO, 1996:4), for example, by working with disabled people to establish self-help community groups, while a community-based social worker supports those with mental and psychosocial issues through counselling, advocacy and support groups. Furthermore, community development workers are community-based resource persons who collaborate with other community activists (like many of the above-mentioned community groups) to help fellow community members to obtain information and resources from service providers with the aim of learning how to progressively meet their needs, achieve goals, realize their aspirations and maintain their well-being. The community development workers can therefore be seen as the link between the people and the government (local, provincial and national). 


\section{POLICY DEVELOPMENT AND BACKGROUND OF THE COMMUNITY DEVELOP- MENT WORKER SYSTEM IN SOUTH AFRICA}

In this section the policy development towards, and the background to, accepting the community development worker system in South Africa are discussed. Since 1994 the government has encouraged community participation and development. This emphasis is evident in various postapartheid policy documents and it is to a large extent a reaction to the autocratic policy approaches that characterised apartheid. The implementation of the Community Development Worker system is an initiative from government to further embrace community involvement in decision making. According to Deputy President Phumzile Mlambo-Ngcuka (South Africa Info, 2005a), the community development workers should act as a link between the government and the community, as well as bring the government closer to the people.

Throughout the post-1994 period of new policy development and legislation in South Africa, the roles, rights and responsibilities of communities have been promoted to reflect citizens' rights under the Constitution of the Republic of South Africa (Act 108 of 1996) (Republic of South Africa, 1996). Section 2.7 of the Reconstruction and Development Programme (RDP) White Paper stresses that "the national government wishes to unlock the political and creative energies of the people and bring government closer to the people ... for the first time in South Africa's history, emerging democratic local authorities must work with community-based organisations and NGOs to establish minimum conditions of good governance and to implement effective development projects" (Republic of South Africa, 1994:19).

In 1996 the shift to the macro-economic Growth, Employment and Redistribution (GEAR) Policy set specific targets for economic growth and for job creation (Department of Finance, 1996). GEAR has been acknowledged as ensuring macro-economic stability while limiting the development agenda of the state (Community-based Worker Project, 2004:16). Development spending priorities, including the provision of social services and economic infrastructure, became subject to greater fiscal discipline and more rigorous cost recovery and had to comply with criteria for financial sustainability. However, the strategy did call for a strengthening of redistributive efforts and improved service delivery through, for example, reprioritising spending to historically disadvantaged communities and focusing welfare spending on assistance to the poor rather than to institutionally-based services.

At the same time the 1997 White Paper for Social Welfare signalled a departure from traditional welfare approaches towards the provision of services that would lead to greater self-sufficiency and sustainability (Ministry for Welfare and Population Development, 1997). The Department of Finance argued that, since social service spending in South Africa was comparatively high, the problems of inadequate service delivery should be addressed by improvements in efficiency, ensuring that people both gain access to these services and that they access them efficiently.

Furthermore, a 1997 Department of Public Service and Administration (DPSA) White Paper on Transforming Public Service Delivery (Republic of South Africa. Department of Public Service and Administration, 1997) promotes these efficiency improvements through a new framework of service-delivery priorities. The emphasis is on "people must come first - customer concept", or Batho Pele. In 1998 the Local Government White Paper (Republic of South Africa, 1998) made the legislative transition towards the notion of "developmental local government", described as "local government committed to working with citizens and groups within the community to find sustainable ways to meet their social and economic and material needs and improve the quality of their lives". 
The South African government's Accelerated and Shared Growth Initiative for South Africa (AsgiSA), launched by President Thabo Mbeki in July 2005 and headed by Deputy President Phumzile Mlambo-Ngcuka, aims to stimulate the country's economy, while also counteracting the effects of apartheid (South Africa Info, 2005a). Its primary aim is to halve unemployment and poverty by 2014 (this is similar to the Millennium Development Goals) (Government Communication and Information Systems [GCIS], 2005). The Department of Trade and Industry is also working on how to create many more opportunities for people in the so-called "second economy", who are finding it hard to find formal employment - or any jobs at all. AsgiSA initiatives must still be adjusted and fine tuned by means of continued consultations.

It is against the above background, which emphasises the need both to engage with communities in a more direct manner and to ensure better access to government services, that the roles and responsibilities of the community development workers have been shaped since 2002. President Thabo Mbeki's State of the Nation Address (February 2003), alluded to earlier, envisioned these community development workers as bringing the government closer to the masses where they live (Baaitjies \& Hinstra, 2005:10). Deputy President Phumzile Mlambo-Ngcuka described the community development workers as "our future managers in the public service" (South Africa Info, 2005b:2). Mbhazima Shilowa (Gauteng Premier) noted that the role of community development workers was to take government directly to the people. "Community development workers would be positioned to help make the machinery of the bureaucracy work more efficiently, increasing the effectiveness of systems of all levels of government and strengthening government's awareness of and capacity to respond to the needs of the people at the local level" (Shilowa, 2005:1).

From this section it can be concluded that community development workers and communitybased workers are not in themselves new concepts, but can be seen within a new context. South Africa has made important progress with the system of community development workers, yet still has a long road ahead. The question remains: what lessons has been the experience of other international programmes in using community-based worker systems? The rest of this paper reflects on the international lessons and their possible application in the South African environment to be able to improve the excellent system that is developing.

\section{INTERNATIONAL LESSONS LEARNED IN THE USE OF COMMUNITY-BASED WORKER SYSTEMS}

\section{Lesson 1: Government's involvement in the community-based worker system is essential}

The international literature suggests that national governments have a vital role to play in supporting the development of community-based worker initiatives (Cruse, 1997:5; Russel \& Schneider, 2000:11; Morgan, 2000:7; Steinitz, n.d.:4; Jones, 1999:87). Various studies have suggested that, where governments accept the potential contribution they can make in community worker projects, whether directly or through other organisations, the programmes have generally achieved higher levels of success (Jones, 2002; Institute of Policy Analysis and Research [IPAR], 2003; Jones, 1998; Platt, Kagwe \& Mwanponda, 2004; Best, 1999). A number of international examples are available in this regard in Africa (Botswana, Rwanda, Tanzania, Ghana, Kenya, Zimbabwe, Uganda, Namibia and Zambia), Asian (Indonesia, Cambodia, Thailand, Mali, Bangladesh, Philippines, China and Nepal) as well as South and Central American countries (El Salvador, Honduras, Jamaica, Panama, and Colombia). 
A good example is the Deliveri Programme in Indonesia, which has been working with the department of livestock services to develop and test a range of community-based services to provide more effective, available and sustainable livestock services (Bahasa, n.d.:1). These community-based animal health worker (CAHW) services have increased the range of services available to farmers. The development of responsibilities by these workers allows the government to focus its limited resources on public services such as quality control, the enforcing of regulations, disease surveillance, livestock movement control, hygiene and research. These community-based services are also easy to access, cheap, complementary to government and private sector services, and they create employment in rural areas (Bahasa, n.d.:7).

Another example is drawn from the health sector. The significant impact of the community-based distribution (CBD) of family planning and reproductive health services is the result, in part, of the political goodwill and support received from respective governments (Botswana, Namibia, Indonesia, Kenya, India, etc) (Cruse, 1997:5). Community health workers (CHW) are not a cheap form of alternative health care (they are volunteers and not professionals), but can more successfully provide affordable first-level contact within a public health service than other health providers. Therefore, community health worker interventions are relatively low in cost compared with a visit to a clinic or an out-patient visit to a community hospital, or a visit to a peri-urban clinic and may be viewed as complementary to the formal health services (Cruse, 1997:10).

In Peru the government and the various tiers of governance play a critical role in providing an enabling framework for the operations of the community-based worker system. A partnership arrangement between the central government, civil society organisations, local government and the community is a workable model for the pro-poor service delivery that is being implemented across Peru (Khanya-African Institute for Community-Driven Development, 2006:22).

There are also examples of programmes that failed as a result of limited government support. For example, Nsutebu, Walley, Mataka and Simon (2001:240) are of the opinion that the limited involvement of governments in the provision of home-based care services appears to be one of the main reasons behind the sparse coverage of home-based care in Africa. Those with experience of the case studies of Lusaka Family Health Trust Home-based Care Project and Ndola Catholic Diocese Home-based Care Programme in Zambia concur that there have been no systematic attempts from the various tiers of government to accelerate and support the development of community-based care and support (Stekelenburg, Kyanamina \& Wolffers, 2003:116). Indeed, according to Russel and Schneider (2000:36), in most countries there are no guidelines for the role of government (national, provincial and local) in this area. Such guidelines need to take into account the respective strengths and weaknesses of government and community organisations, and the need for partnership and mutual respect between these actors. Without political commitment, it is always difficult for the role of these workers to be taken seriously.

What seems evident from international experience is that governments' commitment is essential to community-based worker programmes. This commitment is even more essential in cases where the implementation is undertaken by community-based organisations (CBOs) or nongovernmental organisations (NGOs). However, although this commitment is not directly stated in the international context, it should go beyond financial contributions and rather be considered as a learning curve from communities, through the community-based workers, in order to improve policies and programmes. In South Africa the government is not achieving adequate coordination and integration across departments, agencies and different spheres of government. This lack of functional unity among departments has done considerable damage to sustainable development and further undermined the principle of putting people first (DPLG, 2004:8). Community 
development workers could coordinate and collaborate with other community-based workers and volunteers in the community from other departments. The community development workers and community-based workers programmes could also be linked to existing programmes such as the Youth Service Programme of the National Youth Commission, Free Basic Services, Municipal Infrastructure Grant (MIG), Expanded Public Works Programme (EPWP), Urban Renewal and Development Programme, Integrated Sustainable Rural Development Programme and Local Redistribution Programmes (Presidential Programme, 2004:22).

\section{Lesson 2: Appropriate and continued training of community-based workers is pivotal to the success of the approach}

Community-based worker training emerges from the available international literature as an essential aspect of effective community-based worker systems (Finger, 1999:3; Friedman, 2002:175; Morreira, 1999:14). In general, training should be ongoing (Cruse, 1997:3); community-based (Bhattacharyya, Leban, Winch \& Tien, 2001:22; Mariner, Roeder \& Admassu, 2002:31); problem- and solution-oriented (Advance Africa, 2003:2); and an experiential educational process (Steinitz, n.d.:9; Finger, 1999:3). Three specific points can be made in this regard.

Firstly, training courses for community-based workers should be developed by incorporating ideas from the specific communities and areas where the work is located (Bhattacharyya et al., 2001:22). Much greater success has been achieved through repeated meetings where problems were posed through activities such as role-plays and also where communities identified their own training priorities, concerns, capacities and commitments (Mariner et al., 2002:31). Training should be customised and made relevant to local conditions. Facilitating agents should have a deliberate focus on ensuring that training takes account of cultural and social factors, and should capitalise on the wealth of knowledge of the people. Training should therefore be developed with the people in mind so as to ensure that it is integrated with their cultural values. Every community has both concrete and intangible human needs where community-based workers should be able to assist. Community-based workers need to be capable of dealing with these complex real-life issues and the problems which manifest around them.

Secondly, training tools, as well as manuals and practice opportunities, should be developed (Morgan, 2000:5). The training material should also contain problems and situations that the community-based workers will encounter in their daily routine. Pathfinder and the Catholic AIDS Action in Namibia train volunteers extensively to prepare them for the work they have to perform, but they also provide the volunteers with manuals and opportunities to practice what they have learnt before they are sent into the field (Steinitz, n.d.:9). In Paraguay the CommunityBased Distribution Programme approximates the "learning by doing" style by supplying the volunteers with small manuals that use flowcharts as a basic training tool. A worker follows the flowcharts, flipping to a particular page at each client's answer to specific questions (Finger, 1999:3). This can probably only be used as a guide - often there is more to resolving a problem than following mechanical steps.

Thirdly, follow-up or refresher courses are essential to reinforce and update the knowledge of the community-based workers (Steinitz, n.d.:9). This also assists in their continual professional development (IPAR, 2003:2).

Community development worker training in South Africa focuses on practical exposure in the community - an approach that is emphasised by the "learnership" concept. The training standard for the Community Development Worker Learnership is the Development Practitioner Qualification starting at NQF (National Qualifications Framework) Level 1 and progressing to 
NQF levels four and five. Therefore, the training for community development workers in South Africa is intended to be progressive and lifelong (DPLG, 2004:18). There may be a degree of variation in training to accommodate their specific needs and the adapted roles for the community development workers in their province. Therefore, training cannot therefore be entirely presented in standardised packages as the physical and social milieu of different regions and the composition of target groups could dictate the need for adapting the content to varied situations. Community development worker training in South Africa incorporates the idea of being community specific and there is also an opportunity for the community development worker to obtain formal training as a first step for a career path. The course includes many practical opportunities in that the community development workers "learn by doing", but there does not seem to be any mention of refresher courses and follow-ups. Yes, the training can take place at different levels, but there are no opportunities where the community development workers have specific training sessions along their career paths.

\section{Lesson 3: The significance of community participation}

The community is an indispensable stakeholder in the community-based worker system, but is often left out of the entire equation (Cruse, 1997; Bhattacharyya et al., 2001; Marenga, 2001; Uphoff, 1998; Donahue \& Williamson, 1999; Leksmono \& Young, 2002). To start with, communities should be given the opportunity to establish criteria for the selection of communitybased workers and should also be involved in the selection process of these community workers (Cruse, 1997:22). Furthermore, community involvement is an integral part of community-based workers' motivation (Bhattacharyya et al., 2001; Marenga, 2001; Uphoff, 1998:6). Praise and respect from community residents and peers can motivate community-based workers positively and increase the length of their service (Bhattacharyya et al., 2001:27). Thus, the appreciation of the people they serve is a strong incentive that is often cited as important to community-based workers' job satisfaction (Marenga, 2001:8). Consequently, encouraging communication and interaction between community-based workers and community members is critical towards building an understanding of the community-based workers' role and towards mustering support for their work. But in many communities the potential of the community worker has not been fully realised, because of a poor relationship with the community (Bhattacharyya et al., 2001:25). For example, in the Solomon Islands, $32 \%$ of the former village health workers surveyed left their posts because of a lack of community support.

There are also various other examples where the community and the community-based workers had a good relationship. The International Federation of Red Cross and Red Crescent Societies believes that by using community home-based carers, community participation and involvement are promoted, while at the same time empowering family and community members (Marenga, 2001:8). This consultation with the community also provides the opportunity to increase people's awareness and understanding of HIV and AIDS. Furthermore, through working with the community to assess their vulnerabilities, capabilities and resources, a greater understanding develops of the problems that each family and the community face (Donahue \& Williamson, 1999:1). The Project Concern International in Zambia introduced "participatory learning in action" to a community that were concerned about their children and joined forces with the community to start community schooling. Minnesota International Health Volunteers has trained about 2000 community volunteers in Uganda for a variety of tasks. Community recognition has proved to be a valuable tool in motivating and retaining community volunteers by increasing their status in the community: about $70 \%$ of them have been elected to various positions on their local councils since becoming volunteers (Bhattacharyya et al., 2001:44). 
Communities are also the key to community-based workers operating effectively within the natural resources sector (Uphoff, 1998:6, Jones, 1999). A case in point is Bihar and eastern Pradesh, India, where millions of rural people have access to irrigated lands with good natural resource endowments and potentially high productivity. Despite being well endowed with such natural resources, there is widespread poverty and deprivation, and social and economic marginalisation. Rather than identify technical/productivity options as an entry point, project planners use self-help groups to enhance social capital at the community level and build the financial and human capital of individuals (NRSP - Natural Resource System Programme, 2004:xv). Using such a social development process as an entry point has enabled the projects to reach the poor and the socially disadvantaged and to improve their livelihoods. Project volunteers registered themselves as an NGO, namely the Sustainable Livelihood Promotion Society (SLPS) (Leksmono \& Young, 2002:14). Livestock owners living in rural and marginal areas, who used to have limited access to basic veterinary services, are now able to access basic services at any time, which has led to a significant increase in the cattle population. Individual volunteers have also expanded their role to also supplying agricultural inputs together with related information on a commercial basis. Most of the community animal health workers have within three or four months been able to generate an income from the work in which they have been engaged, thereby providing a strong incentive for them to remain in the job, while also ensuring the sustainability of the service. Efficiency in treating animal diseases improved substantially: in 1998 the cost to government of treating one case was between Indonesian Rupiah (IDR) 111,000 to 212,000, while by 2000 the CAHWs were providing the same service for only IDR 5,000 to 35,000. The implementation of community animal health workers thus significantly reduced government spending (Leksmono \& Young, 2002:16).

The Deliveri Project's community animal health workers also contributed to poverty alleviation in India. The Deliveri socio-economic impact report showed a significant redistribution of income from 1997 to 2000 in the districts of Barru and Bulukumba (South Sulawesi). While the proportion of respondents in the "medium"-wealth ranking category in each district remained constant in 1997 and 2000, both years saw an increase in the proportion of respondents falling into the "rich" category, as well as a reduction in the proportion falling into the "poor" category (Leksmono \& Young, 2002:16). So these local communities, who used free but intermittent and poor-quality government services, welcome the opportunity to be in control of service delivery through engaging community-based workers.

In South Africa people do not get the vital information they need to deal with some of the challenges that face them, and decisions taken by the national government do not seem to reach ordinary people in the under-served and rural areas as quickly as they should. Where information is actually provided, the language is often too difficult for ordinary people to understand. Community development workers will speed up the dissemination of the information to disadvantaged people who need to access programmes designed for their benefit (DPLG, 2004:11). A question that can be asked is whether the community development workers are not simply a glorified version of social workers. Is it also a good idea that they should always drawn from within the community where they live? Does this not make them very susceptible to being intimidated?

Apart from the community support, there also need to be various other ways for the communitybased workers to obtain support. Through supervision programmes, management could maintain the morale of the volunteers when they realise that their work is worthwhile. 


\section{Lesson 4: The importance of support, supervision and accountability}

Volunteers and community development workers need support for, and recognition of, the valuable and sometimes stressful service they provide (Frontiers, 2002; Steinitz, n.d.; Morreira, 1999; Bhattacharyya et al., 2001; Blinkhoff, Bukanga, Syamalevwe \& Williams, 2001). A number of comments should be made in this respect.

Firstly, the literature suggests that support from programme management is important, not only in helping to maintain high morale among volunteers, but also in helping to make their work more effective (Bhattacharyya et al., 2001:19). According to Blinkhoff et al. (2001:45), this support from project management demonstrates that they value all volunteers as individuals and appreciate their contribution to the programme.

Secondly, the international experience suggests a number of ways to provide support. Supervisors can give the community-based worker opportunities to discuss problems, exchange information and take advantage of the continuing education. In addition, regular supervisory visits help reduce the feelings of isolation that often characterise a community-based worker's occupation (Bhattacharyya et al., 2001:19).

Thirdly, to be effective, supervisory visits should be regular and based on a common understanding of the purpose of the visit. Community-based workers appreciate good supervision given with the honest intention of building capacity and of mentoring (Bhattacharyya et al., 2001:20). In this regard, Chege and Askew (in Finger, 1999:2) found a statistically significant relationship between the frequency of supervision and the agent's output.

Fourthly, recommendations to improve supervision include the use of supervision checklists, maintaining a firm monthly schedule and using full-time, field-based staff to supervise volunteers (Finger, 1999:2).

Fifthly, despite the importance of the above aspects, governments in resource-limited countries rarely undertake the commitment to provide quality assurance and material support that should accompany community-based worker activity (Steinitz, n.d.:4). This situation often leaves the volunteers feeling unsupported and without the means to make a difference, especially in dire situations (Marenga, 2001:12). Volunteers in these conditions complain of burnout and frustration, which further suggests that the coordination and cooperation of support systems between local communities and government in resource-limited countries are often weak. Stekelenburg et al. (2003:115) argue that Community Health Workers in Kalabo District, Zambia do not, for example, benefit from supervision visits. All too often, the visits only serve as mere reporting systems to higher authorities that the activity has been fully completed. Very few are concerned with what has actually been achieved (Stekelenburg et al., 2003:116) or about the well-being of the community health workers.

There can be no doubt that an effective supervisory system is essential to the community-based workers. In the South African context, in theory, community development workers (three per ward) are accountable to a community development supervisor (CDS) (one per ward) who guides, mentors and trains them. The Community Development Supervisor is in turn accountable to the local Ward Development Association (WDA), which provides governance for the programme (DPLG, 2004:19). Each local municipality has a Community Development Manager (CDM) (one per municipality) to which all of these Ward Development Associations report.

Despite the overall system being ruled by the National Policy Framework for Community Development Workers, a number of comments should be made or questions asked with regard to the South African community development worker system. Is there enough capacity to ensure 
that essential support is provided? It seems as if the support mechanism is an internal structure. What type of support and supervision do they receive from the responsible department as well as from the various municipalities? The overall danger exists (and this has been found in some of the international experience as well) that community development workers do not receive enough high-level support. Community development managers are municipal personnel and civil servants with professional training in community development, management or other appropriate disciplines, but do they "really" have time to attend to community development worker issues over and above their normal municipal development responsibilities? There is a long line of supervision and reporting - do $A L L$ the original concerns that the community development worker brings from the community receive the necessary attention? Ward development associations appoint, remunerate and manage community development supervisors, so do they simply report what the associations "want to hear" or do they express all the community's concerns? Are these community development workers not too junior in the hierarchy to make an impact on the conditions that need to be changed? Do they have sufficient authority to influence the decisions made by the municipal managers? According to Jones and Nelson (2005:12), community development workers are not seen as having anything worthwhile to contribute to policy debates, and communication up the chain is usually ignored. The best way of communicating to policy makers is by using the evaluation process. The social work sector has excellent examples of supervision practices and can therefore be used in these situations.

\section{IMPLICATIONS OF INTERNATIONAL EXAMPLES FOR SOUTH AFRICA}

Certain critical issues emerge from the literature on current practice. They provide a useful framework for analysis and suggest how improvements may be incorporated into future policy and programmes in South Africa. These suggestions could provide guidelines to be used in conjunction with other programmes to move a step forward in creating better lives for the people of South Africa. Many of the problems that South African communities are experiencing have already been encountered and analysed in other countries.

Firstly, though it seems as if large projects run by national governments have not worked internationally, smaller projects, supported by government, should be attempted. This could be seen as a shortcoming or a positive implication for South Africa, because the Community Development Worker Programme is a national project, but is run at the municipal ward level. According to the DPLG (2004:7), the Community Development Worker Programme has not only been canvassed by the highest executive government level, but all spheres of government have become involved. The national sphere of government bears the major responsibility for driving the Programme and establishing equitable funding arrangements and a standardised approach (DPLG, 2004:28). In addition, the Department of Provincial and Local Government has the important role of providing national guidelines and adjusting these to specific target districts, and adapting generic approaches to specific language and cultural needs (DPLG, 2004:29). Furthermore, it is envisaged that district and local municipalities will coordinate their efforts to promote participatory direct democracy in ward substructures managed by democratically elected ward development associations (DPLG, 2004:30). What seems to be lacking is a system to learn from the experiences of community-based workers. It is one thing to ensure that the systems are in place to implement a community-based worker framework, but it is more challenging to ensure that government officials at all levels of government listen to and operationalise the experiences of community-based workers into policy. Community development workers are currently being employed by district municipalities and deployed to local municipalities. Is this a wise decision considering the tensions that exist between the district and local levels? 
Secondly, the training of community-based workers in South Africa should be standardised according to NQF specifications, but the international experience is that training should incorporate ideas from the community and should be reworked according to the communities' needs. Not all communities in South Africa not have the same needs. A positive aspect of the Community Development Worker Programme is that there are different levels of training and refresher courses where the community development worker can improve themselves and their skills. The question arises as to why the community development workers should be trained on the job. Why are they not already competent to do the job when they are appointed?

The initial contact phase or community-entry phase is of crucial importance and involves the community development worker entering into the social life experience of that community (DPLG, 2004:18). The community development worker system can perhaps be said to be yet another way the government has established "a new initiative of keeping the masses quiet". Many people are beginning to think that the Community Development Worker Programme has turned out to be, as was feared, just another layer of expensive, incompetent bureaucratic inertia.

Lastly, a comprehensive support structure ranging from the national to the local level is a prerequisite if the programme is to succeed (DPLG, 2004:25). Experience has shown that the main reason for the failure of national programmes deploying community-based workers is that inadequate attention is paid to the provision of institutional support such as adequate training, technical expertise, close supervision, meticulous financial and administrative controls, etc.

Nevertheless, the President in his State of the Nation Address in 2003 also emphasised that the process of implementation of the Community Development Worker Project should be a learning process and that there is a need to be flexible to accommodate changes during the roll-out of the Community Development Worker Programme (DPLG, 2004:6).

\section{CONCLUSION}

Community-based worker activity is not sector specific, but is rather an approach which can be utilised and adapted in different contexts. Indeed, international experience indicates that the spread and focus of community-based workers are diverse. Information about their activity and impact is informal; capturing reliable data about what is often a voluntary activity at the micro level (within people's homes or community settings) is problematic. Yet from the material reviewed it can be seen that the key common denominator is that the community-based worker is a community member who delivers a service to other community members at the micro level.

In summary, five basic recommendations emerged from the literature for the improvement of the community-based worker system in South Africa. These should be addressed in legislation which is being developed to incorporate community-based worker systems in South Africa. These recommendations should not only be written as national frameworks but also as policy. Firstly, the government should support the activities of community-based workers - in all spheres. Supervision and accountability of the community-based workers also count as support and encouragement for job motivation. Secondly, communities should be actively involved in all the processes of the community-based worker approach. To incorporate the community in the planning, implementation and evaluation of the programme means that, in the long run, the programme could be more sustainable. Thirdly, community-based workers should receive good training, either from the government or from non-government organisations, so that they can build capacity to manage their own programmes. There should also be post-course support for community-based workers so that they are informed about the latest methods and treatment, etc. Fourthly, the support which is given to community-based workers should be long-term support 
and not only provided during the implementation or training phase. They should be assisted with different aspects, perhaps on a monthly or quarterly basis. Lastly, there are many funded programmes around the world that make use of community-based workers to make their programmes sustainable. Yet not much has been written about community-based workers as such. What does seem to be important, though, is that the programme should be successful as a whole, rather than dwelling on the details as to how success is achieved and by whom. For example, despite the growth of interest in community health worker interventions and the evaluation of several programmes over the past decade, few of these projects and success stories have actually been published or widely circulated.

\section{ACKNOWLEDGEMENTS}

The information in this article was part of a literature review for the African Institute of Community Driven Development (formerly Khanya - managing rural change). It was incorporated into their Community-based Worker Project funded by the UK Department for International Development. The researcher would also like to make special mention of an excellent mentor (Dr Lochner Marais - Senior Researcher at the Centre for Development Support, University of the Free State) and thank him for his guidance and patience as a critical reader.

\section{REFERENCES}

ADVANCE AFRICA. 2003. Addressing FP/RH within community-based distribution [online]. Available: http://www.advanceafrica.org/what we do/Expandng Community-based Initiatives/CB. [Rev. 11 May 2005].

BAAITJIES, R. \& HINSTRA, Z. 2005. Community development workers. At the heart of participatory democracy and developmental government. Local Government Bulletin, 7(5):1011.

BAHASA. n.d. Community-based animal health services. Indonesia: Deliveri Programme, Indonesia [online]. Available: http://www.deliveri.org/guidelines/ implementation/ig 4/ig 4 summary.htm. [Rev. 14 March 2005].

BEST, K. 1999. CARE Project Enlists Community Support. Network, 19(3):1-3 [online]. Available: www.fhi.org/en/RH/Pubs/network/v19 3/four_cbd_programs.htm. [Rev. 11 May 2005].

BHATTACHARYYA, K., LEBAN, K., WINCH, P. \& TIEN, M. 2001. Community health worker incentives and disincentives: How they affect motivation, retention, and sustainability. Arlington, Virginia: Basics II, United States Agency for International Development.

BLINKHOFF, P., BUKANGA, E., SYAMALEVWE, B. \& WILLIAMS, G. 2001. Under the Mupundu Tree. Volunteers in home care for people with HIV and AIDS and TB in Zambia's Copperbelt. London: ACTIONAID.

COMMUNITY-BASED WORKER PROJECT. 2004. South Africa in-country review report. Community-based worker project. South Africa: African Institute for Community Driven Development (formerly Khanya).

CRUSE, D. 1997. Community health workers in South Africa: Information for provincial policy makers. Durban: Health Systems Trust.

DEPARTMENT OF FINANCE. 1996. Growth, employment and redistribution. A macroeconomic strategy. Pretoria: Department of Finance. 
DONAHUE, J. \& WILLIAMSON, J. 1999. Community mobilization to mitigate the impacts of HIV/AIDS. United States: Displaced Children and Orphan Fund.

DPLG - DEPARTMENT OF PROVINCIAL AND LOCAL GOVERNMENT. 2004. A National Policy Framework for Community Development Workers in South Africa. Discussion Document. Pretoria: Community Development.

DPLG - DEPARTMENT OF PROVINCIAL AND LOCAL GOVERNMENT. 2005. Draft National Policy Framework for Public Participation. Pretoria: Public Participation and Empowerment Chief Directorate.

FINGER, W.R. 1999. Motivating community-based worker. Network, 19(3):1-3.

FRIEDMAN, I. 2002. Community-based health workers. South Africa: SEED Trust Health Programme.

FRONTIERS. 2002. Best practices in CBD Programs in sub-Saharan Africa: Lessons learned from research and evaluation [online]. Available: http://www.eldis.org/static/DOC15604.htm. [Rev. 23 May 2005].

GOVERNMENT COMMUNICATION AND INFORMATION SYSTEMS (GCIS). 2005. Creating work, and growing economy. Vuk'zenzele, 1(2). [online]. Available: http://www.info.gov.za/vukuzenzele/number2/page6.htm. [Rev. 22 June 2006].

HOLLOWAY, S., LEE, L. \& McCONKEY, R. 1999. Meeting the training needs of communitybased service personnel in Africa through video-based training courses. Disability and Rehabilitation, 21(9):448-454.

IPAR - INSTITUTE OF POLICY ANALYSIS AND RESEARCH. 2003. Policy Requirements to Accommodate Community-based Animal Health Workers in Kenya. Policy Brief, 9(2):1-4.

JONES, B.T.B. 1998. Community management of natural resources in Namibia. Scandinavian Seminar College's Africa Project. Windhoek: IIED.

JONES, B.T.B. 1999. Community-based natural resources in Botswana and Namibia: An inventory and preliminary analysis of progress. Windhoek: IIED.

JONES, B.T.B. 2002. Chobe Enclave, Botswana. Lessons learnt from a CBNRM Project 1993-2002. Botswana: CBNRM Support Programme.

JONES, S. \& NELSON, N. (eds) 2005. Practitioners and poverty alleviation. Influencing urban policy from the ground up. Warwickshire: ITDG Publishing.

KHANYA-AFRICAN INSTITUTE FOR COMMUNITY-DRIVEN DEVELOPMENT. 2006. Peru Study Tour Report on Community Based Worker Systems. Bloemfontein: Khanya. [online]. Available: http://www.Khanya -aicdd.org/photo_root/publications/peru\%20 final\%20report 06_07_15.pdf. [Rev. 12 October 2006].

LEKSMONO, C.S. \& YOUNG, J. 2002. Community-based animal health workers and institutional change: The DELIVERI Project in Indonesia. Participatory Learning and Action Notes, 45:13-16.

MAKAN, B. 1997. An economic analysis of Community Health Worker Programmes in the Western Cape Province. South Africa: Health Systems Trust.

MARENGA, C. 2001. Home-based care for people living with HIV/AIDS. United Kingdom: International Federation of Red Cross and Red Crescent Societies. 
MARINER, J., ROEDER, P. \& ADMASSU, B. 2002. Community participation and global eradication of rinderpest. Participatory Learning and Action Notes, 45:29-33.

MORGAN, R. 2000. Pathfinder's community-based projects address barriers to reproductive health services. Pathpapers, 1(1):1-10.

MORREIRA, S. (ed) 1999. How can we help? Approaches to community-based care. Zimbabwe: Child Protection Society.

NRSP - NATURAL RESOURCE SYSTEM PROGRAMME. 2004. NRSP Annual Report 2003-2004 Part 1 - Project Success Stories [online]. Available: www.nrsp.co.uk. [Rev. 18 May 2005].

NSUTEBU, E.F., WALLEY, J.D. MATAKA, E. \& SIMON, C. 2001. Scaling-up HIV and AIDS and TB home-based care: Lessons form Zambia. Health Policy and Planning, 16(3):240-247.

PLATT, G., KAGWE, P. \& MWANPONDA, I. 2004. Beyond home-based care in Kenya. Kenya: Pathfinder International.

PRESIDENTIAL PROGRAMME. 2004. A handbook on community development workers in South Africa. Pretoria: Department of Provincial and Local Government.

REPUBLIC OF SOUTH AFRICA. MINISTRY IN THE OFFICE OF THE PRESIDENT. 1994. Reconstruction and Development Programme (RDP) White Paper. Government Gazette, Vol. 353, No. 16085 (23 November 1994). Pretoria: GOVERNMENT PRINTER. [online]. Available: http://www. info.gov.za/ gazette/whitepaper/1994/16085.pdf\#search=\%22Reconstruction\%20and\%20development\%20programme\%20white\%20paper\%22. [Rev. 25 August 2006].

REPUBLIC OF SOUTH AFRICA. 1996. Constitution of the Republic of South Africa Act No. 108 of 1996. Pretoria: Government Printers. [online]. Available: http://www.info.gov.za/documents/constitution/index.htm. [Rev. 5 May 2005].

REPUBLIC OF SOUTH AFRICA. DEPARTMENT OF PUBLIC SERVICE AND ADMINISTRATION. 1997. White Paper on Transforming Public Service Delivery. Government Gazette, Vol. 388, No. 18340 (18 September 1997). Pretoria: Government Printers.

REPUBLIC OF SOUTH AFRICA. MINISTRY FOR WELFARE AND POPULATION DEVELOPMENT. 1997. White Paper for Social Welfare. Government Gazette, No. 1108 (8 August 1997). Pretoria: Government Printers.

REPUBLIC OF SOUTH AFRICA. DEPARTMENT OF LOCAL GOVERNMENT. 1998. White Paper of Local Government Department of Local Government. Government Gazette, (9 March 1998). Pretoria: Government Printers.

RIVIERE-CINNAMOND, A. \& EREGAE, M. 2003. Community-based animal workers (CAHWs) in pastoralist areas of Kenya: A study on selection process, impact and sustainability. Kenya: Public Health and Policy Department.

ROZEMEIJER, N. \& VAN DER JAGT, C. 2000. Community-based Natural Resources Management (CBNRM) in Botswana. How community-based is CBNRM in Botswana? Gaborone: CBNRM Support Programme.

RUSSEL, M. \& SCHNEIDER, H. 2000. A rapid appraisal of community-based HIV AND AIDS Care and Support Programmes in South Africa. Johannesburg: Centre for Health Policy [on line]. Available: http://www.hst.org.za/uploads/files/hivsupp.pdf. [Rev. 26 February 2005]. 
SHILOWA, M. 2005. Launch of the Community Development Workers Programme in Gauteng. Johannesburg: Gauteng Provincial Government [online]. Available: http://www.gpg. gov.za/docs/sp/2005/sp0514.html. [Rev. 5 May 2006].

SIVARAM, S. \& CELENTANO, D.D. 2003. Training outreach workers for AIDS prevention in rural India: Is it sustainable? Health Policy and Planning, 18(4):411-420.

SOUTH AFRICA INFO. 2005a. AsgiSA: Accelerated growth for all. [online]. Available: http://www.southafrica.info/doing_business/economy/development/ asgi-sa.htm. [Rev. 26 June 2006].

SOUTH AFRICA INFO. 2005b. South Africa's Community Workers. Buanews, 28 November 2005.

STEINITZ, L.Y. n.d. When spider webs unite: The work of volunteers in providing homebased care in Namibia. Windhoek: Catholic AIDS Action in Namibia [online]. Available: http://www.caa.org.na/Volunteers\%20Work/When\%20Spider\%20Webs\%20Unite\%20Jan03.doc. [Rev. 28 February 2005].

STEKELENBURG, J., KYANAMINA, S.S. \& WOLFFERS, I. 2003. Poor performance of community health workers in Kalabo District, Zambia. Health Policy, 65:109-118.

UPHOFF, N. 1998. Community-based natural resources management: Connecting micro and macro processes, and people with their environments. Plenary presentation at the International CBNRM Workshop, Washington DC, 10-14 May 1998.

WORLD HEALTH ORGANISATION (WHO). 1996. Guidelines for conducting, monitoring and self-assessment of community-based rehabilitation programmes: Using evaluation information to improve programmes. International Disability Consortium, Geneva. [online]. Available: http://www.who.int/ncd/disability/ publications.htm. [Rev. 12 April 2005].

Deidré van Rooyen, Researcher, Centre for Development Support, University of the Free State, Bloemfontein, South Africa. 